\title{
PENGEMBANGAN LANJUTAN APLIKASI INDONESIA INTEGRATED ROAD MANAGEMENT SYSTEM DI DIREKTORAT JENDERAL BINA MARGA
}

\author{
Hartanto \\ Sekolah Tinggi Manajemen Informatika dan Komputer LIKMI \\ Jl. Ir. H. Juanda 96 Bandung 40132 \\ hartanto_27@yahoo.co.id
}

\begin{abstract}
ABSTRAK
Penelitian ini bertujuan untuk menjelaskan pengembangan lanjutan aplikasi Indonesia Integrated Road Management System (IRMS) di Direktorat Jenderal Bina Marga yang mendukung manajemen aset (terdiri dari jalan, jembatan, dan keselamatan pengguna) di Indonesia yang berbasis web dengan sistem pengelolaan basis data relasional (RDBMS) dan menyimpan database aplikasi, database spasial dengan memanfaatkan Sistem Informasi Geografis berbasis server untuk menyebarkan data spasial.

Penelitian ini menjelaskan tahapan pengembangan aplikasi IRMS serta fitur dan modulmodul yang terdapat didalamnya. Aplikasi IRMS juga menyimpan semua data secara terpusat (aset jalan, jembatan, kondisi, riwayat pemeliharaan, material, kepadatan lalu lintas, data tilang, dan korban kecelakaan) di Indonesia sehingga dapat melakukan analisa untuk menentukan perlakuan tingkat perbaikan jalan, memprediksi kondisi jembatan, dan mengidentifikasi lokasi rawan kecelakaan, menyusun rencana dan anggaran serta membuat rencana pencegahan sebelum terjadinya kerusakan yang parah.
\end{abstract}

Kata kunci : IRMS, sistem informasi geografis, jaringan jalan, jembatan, keselamatan pengguna

\section{PENDAHULUAN}

Penelitian ini berjudul pengembangan Indonesia Integrated Road Management System (IRMS) Tingkat Lanjut di Direktorat Jenderal Bina Marga bermaksud untuk menjelaskan tahapan lanjutan pengembangan aplikasi IRMS yang merupakan suatu aplikasi manajemen aset (terdiri dari jalan, jembatan, dan keselamatan pengguna) berbasis web dengan sistem pengelolaan basis data relasional (RDBMS) yang menyimpan database aplikasi dan database spasial dengan memanfaatkan Sistem Informasi Geografis (SIG) berbasis server untuk menyebarkan data spasial.

Dengan adanya penerapan aplikasi IRMS diharapkan tersedianya pangkalan data jaringan Jalan dan jembatan yang tersusun secara sistematis dan teratur, sehingga dapat digunakan dalam program perencanaan, penyusunan anggaran, dan penanganan jalan, dan jembatan serta didukung dengan data keselamatan pengguna yang dapat membantu dalam perancangan jalan dan jembatan. 


\section{TINJAUAN PUSTAKA}

Aplikasi IRMS merupakan suatu sistem pengelolaan jalan dan jembatan yang terintegrasi. Aplikasi ini mencakup perencanaan, perbaikan, pengelolaan lainnya termasuk ruas-ruas jalan yang masih dan dalam proses pembangunan baru untuk perencanaan dan penyusunan program jalan dan jembatan dengan mempertimbangkan faktor keselamatan penggunanya di Indonesia. [2]

Aplikasi IRMS memiliki pengelolaan basis data oleh suatu perangkat lunak yang spesifik. Perangkat lunak ini yang disebut DBMS (Database Management System). Perangkat lunak ini berfungsi untuk mengorganisasi, menyimpan, mengubah dan mengambil data kembali. Perangkat lunak ini juga menerapkan mekanisme pengamanan data, pemakaian data bersama dari banyak pengguna, keakuratan/konsistensi data. Perangkat Lunak DBMS yang digunakan adalah Oracle. Aplikasi IRMS ini menggunakan Oracle Database versi 12.2.0.1. dalam bentuk Oracle Database Enterprise Edition (EE) yang menawarkan kelebihan dalam hal skalabilitas dan reliabilitas dan tidak dibatasi oleh ketersediaan sumber daya server untuk database. Database memberikan sejumlah pilihan fitur dalah hal Ketersediaan (Availability), Skalabilitas, Analitik, Kinerja, Keamanan, Pengelola, Pengembangan dan Integrasi. Hal ini bertujuan untuk meningkatkan dan melengkapi fungsi database sesuai kebutuhan pengguna.

a. Ketersediaan (Availability)

Oracle Active Data Guard (Oracle Data Guard) sebagai fitur tambahan, memungkinkan akses read-only terhadap data yang terdapat pada standby database untuk mengurangi beban kegiatan utama seperti pelaporan, query khusus, ekstraksi dan backup, menyediakan pilihan untuk mengelola beban kerja melalui replikasi database dan mengembangkan layanan terotomatisasi.

b. Skalabilitas

Oracle Real Application Clusters (RAC) menyediakan kemampuan untuk menangani database failover dan ketersediaan yang tinggi dalam bentuk rolling upgrades, migrasi instance secara online, keberlanjutan applikasi dan manajemen layanan yang terotomatisasi.

c. Analitik

Oracle Advanced Analytics memungkinkan akses kedalam algoritma data mining database dan penggunaan fungsi Oracle R Enterprise yang terintegrasi dengan bahasa pemrograman statistik open-source R. Oracle On-Line Analytical Processing (OLAP) adalah penerapan online analytical processing pada Oracle.

d. Kinerja (Performance)

Oracle Advanced Compression melengkapi fitur kompresi tabel dasar Enterprise Edition dengan kompresi data secara menyeluruh. Oracle Database In-Memory adalah penyimpanan data berorientasi kolom. Oracle Real Application Testing memungkinkan pengujian perubahan sistem dalam bentuk simulasi beban kerja tingkat produksi dan penggunaan. Oracle TimesTen Application-Tier Database Cache untuk meningkatkan waktu respon.

e. Keamanan

Oracle Advanced Security menyediakan enkripsi data transparan yang memungkinkan enkripsi data yang tersimpan dalam database, dan di-ekspor menggunakan Data Pump, atau backup menggunakan Oracle Recovery Manager, dan penyuntingan terhadap data sensitif yang dikembalikan pada aplikasi database. Oracle Database Vault melakukan pembagian tugas dalam hal prinsip pemberian hak istimewa dan pengendalian akses 
data, memungkinkan melindungi data aplikasi. Oracle Label Security adalah kerangka kerja yang canggih dan fleksibel dalam penerapan pengendalian akses berbasis label.

f. Pengelolaan

Oracle Multitenant adalah kemampuan yang memungkinkan konsolidasi database dan menyediakan lapisan abstraksi tambahan. Dalam konfigurasi multitenant, satu instance database Oracle yang dikenal dengan "container database" (CDB) berperan sebagai sistem database pemersatu untuk mengumpulkan sampai 252 objek database yang portabel yang disebut dengan "pluggable databases" (PDB).

g. Pengembangan.

Oracle Spatial and Graph melengkapi fitur Oracle Locator dengan kemampuan spasial lanjut yang memungkinkan pengembangan Sistem Informasi Geografis (SIG) yang kompleks dan mencakup model data jaringan.

h. Integrasi.

Oracle GoldenGate 11g (Perolehan data secara real time dan terdistribusi). [3]

Aplikasi IRMS ini juga di dalamnya memiliki aplikasi yang merupakan bagian dari Sistem Informasi Geografis. Aplikasi Sistem Informasi geografis (SIG) yang digunakan adalah ArcGIS yang diproduksi oleh Esri.

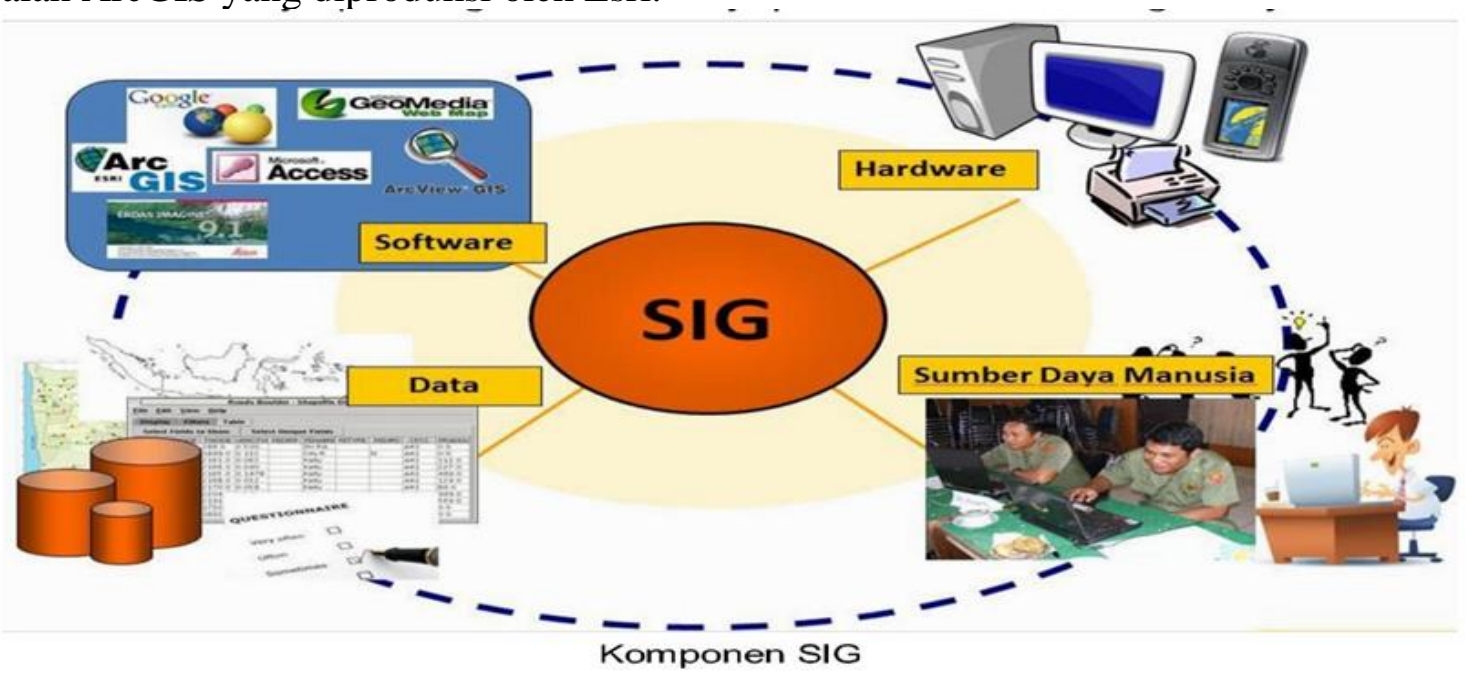

Gambar 1. Komponen SIG berikut:

ArcGIS merupakan perangkat lunak berbasis Windows yang memiliki jenis sebagai

a. ArcReader, yang memungkinkan pengguna menampilkan peta yang dibuat menggunakan produk ArcGIS lainnya.

b. ArcGIS Desktop, memiliki tiga tingkat lisensi:

1) ArcView memungkinkan pengguna menampilkan data spasial, membuat peta berlapis, serta melakukan analisis spasial dasar.

2) ArcEditor memiliki kemampuan sebagaimana ArcView dengan tambahan peralatan untuk memanipulasi berkas shapefile dab geodatabase.

3) ArcInfo memiliki kemampuan sebagaimana ArcEditor dengan tambahan fungsi manipulasi data, penyuntingan, dan analisis.

c. ArcGIS berbasis server, serta produk ArcGIS untuk PDA. 
Dengan adanya SIG maka akan mempermudah pengguna untuk menganalisis, mencari suatu informasi sehingga dapat membantu pengguna dalam mengambil suatu keputusan berdasarkan data/ fakta yang terjadi. SIG juga dapat menghasilkan data spasial yang susunan geometrinya mendekati keadaan sebenarnya dengan cepat dan rinci. [1]

\section{HASIL DAN PEMBAHASAN}

Berdasarkan aplikasi IRMS yang telah dikembangkan, maka aplikasi ini memiliki 4 modul utama, yaitu:

a. Analis Portofolio/Trade-off Analysis.

b. Manajemen Aset Perkerasan Jalan.

c. Manajemen Aset Jembatan.

d. Manajemen Keselamatan.

Pada aplikasi IRMS dapat dilakukan pengaturan pengguna, hak akses, tampilan, keamanan, pengelolaan data, Application Program Interface (API) dalam bentuk REST untuk integrasi, memiliki fungsi reporting/dashboard, GIS Explorer dan LRS Gateway.

a. Modul Trade Off Analysis mengkombinasikan analisis lintas sektor (Jalan dan Jembatan) yang bertujuan untuk mengoptimasi alokasi budget lintas sektor, serta menganalisis dampak keterlambatan proyek, dan menghasilkan laporan dalam bentuk tampilan grafik dan peta.

b. Modul Manajemen Aset Perkerasan Jalan. Modul Manajemen Aset Perkerasan Jalan. memiliki arsitektur diagram seperti Gambar 2. Sistem analisis-pelaporan Perkerasan Jalan disusun seperti pada Gambar 3.



Gambar 2. Arsitektur Diagram Manajemen Jalan Berbasis Spasial 


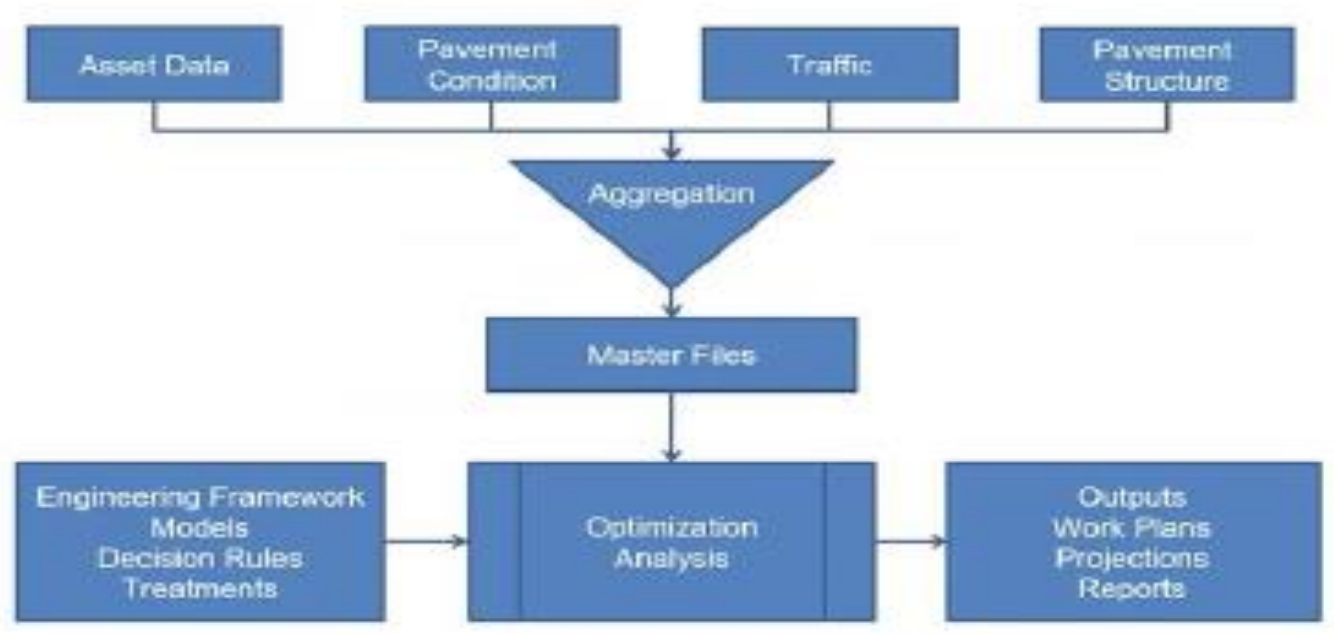

Gambar 3. Analisis Perkerasan Jalan

Menu dan fungsi yang terdapat pada Modul Perkerasan Jalan terdiri dari bagian Setup dan Database, Analisis, dan Reports. Pada bagian Setup dan Database terdapat Menu seperti Gambar 4. Pada bagian Analisis terdapat Menu seperti Gambar 5. Sedangkan Pelaporan dapat ditampilkan dalam bentuk Peta GIS, Laporan (Reports) dan Dashboards.

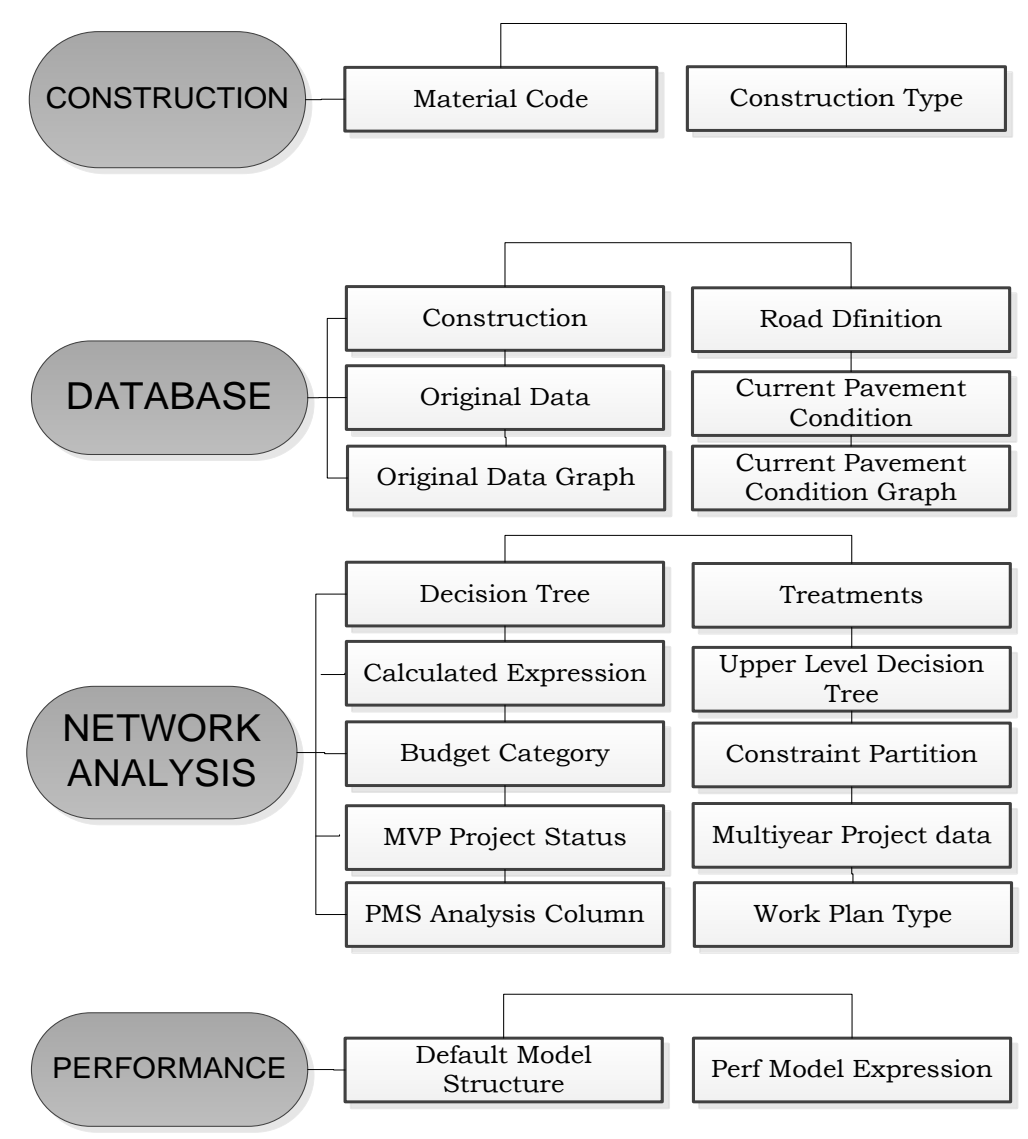

Gambar 4. Modul Setup dan Database Perkerasan Jalan. 


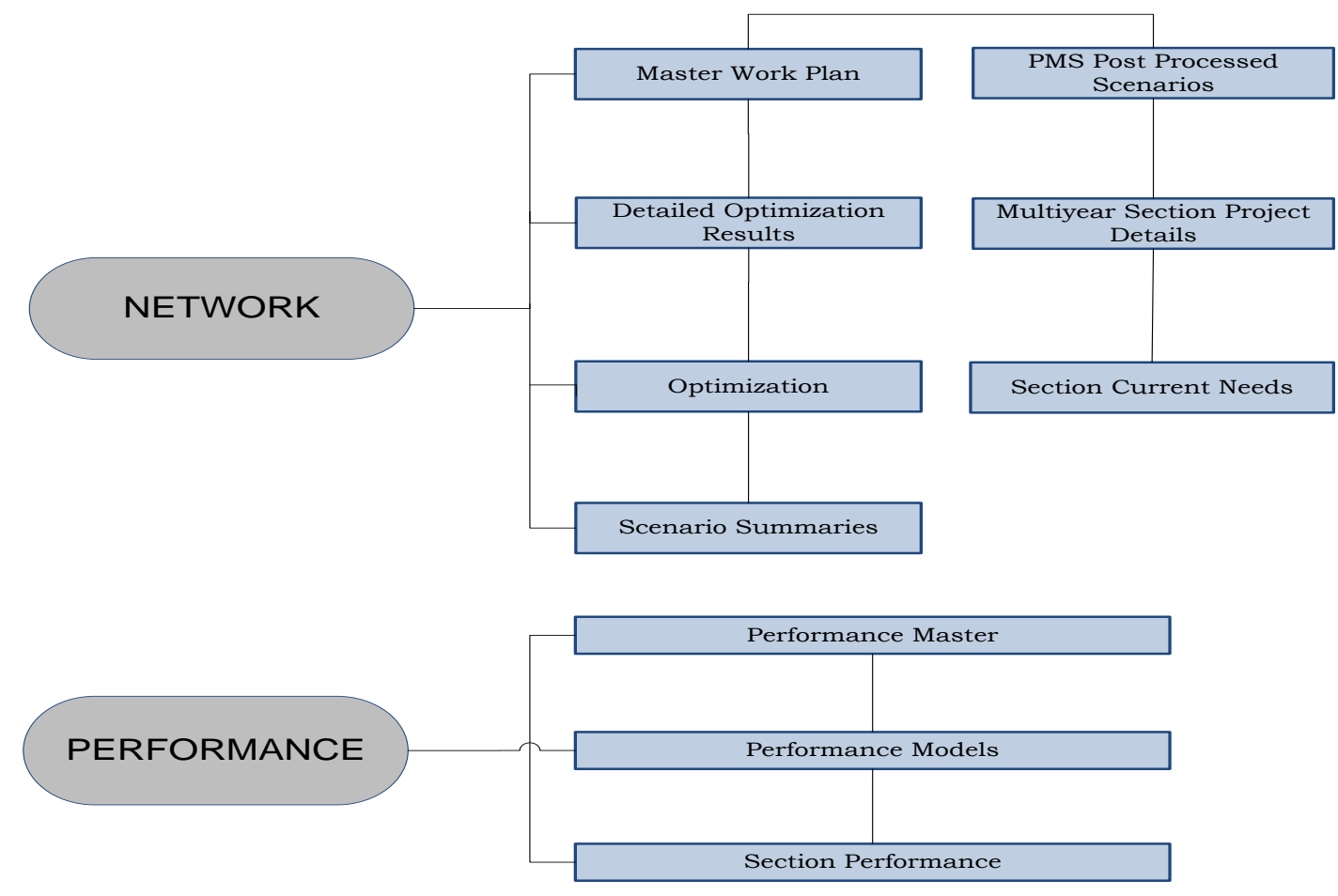

Gambar 5. Modul Analisis Perkerasan Jalan.

c. Modul Manajemen Aset Jembatan

Sistem analisis-pelaporan Jembatan seperti yang dapat dilihat pada Gambar 6 .

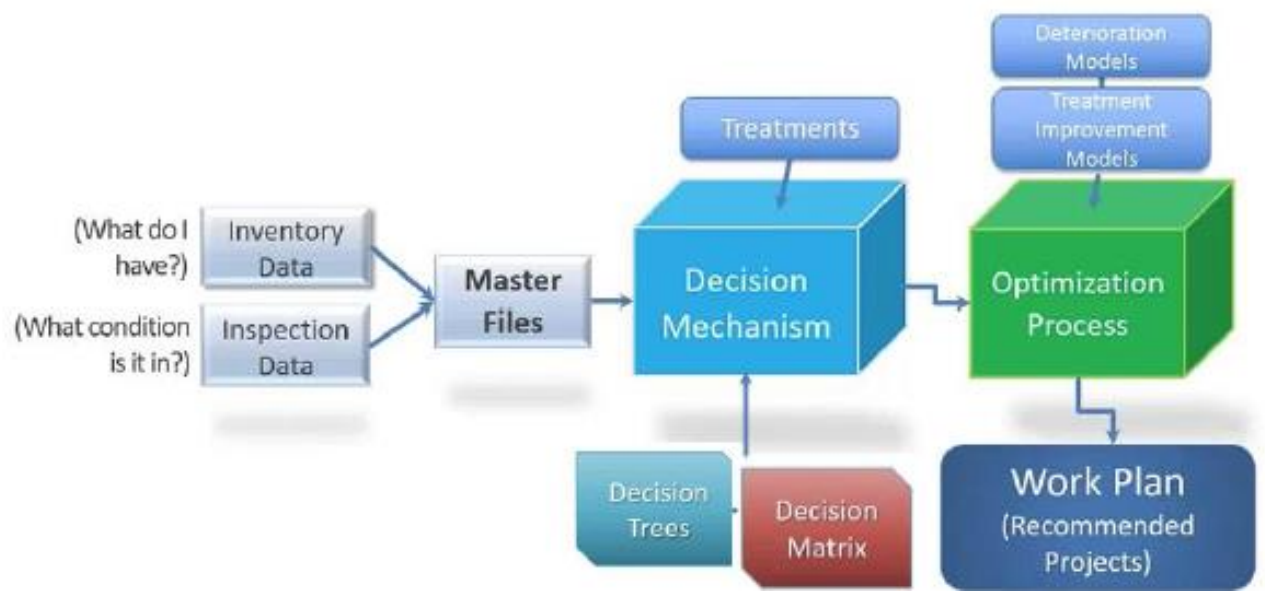

Gambar 6. Analisis Jembatan

Menu dan fungsi yang terdapat pada Modul Jembatan terdiri dari bagian Setup dan Database, Analisis, dan Reports. Pada bagian Setup dan Database terdapat Menu seperti Gambar 7. Pada bagian Analisis terdapat Menu seperti Gambar 8. Sedangkan Pelaporan dapat ditampilkan dalam bentuk Peta GIS, Laporan (Reports) dan Dashboards. 


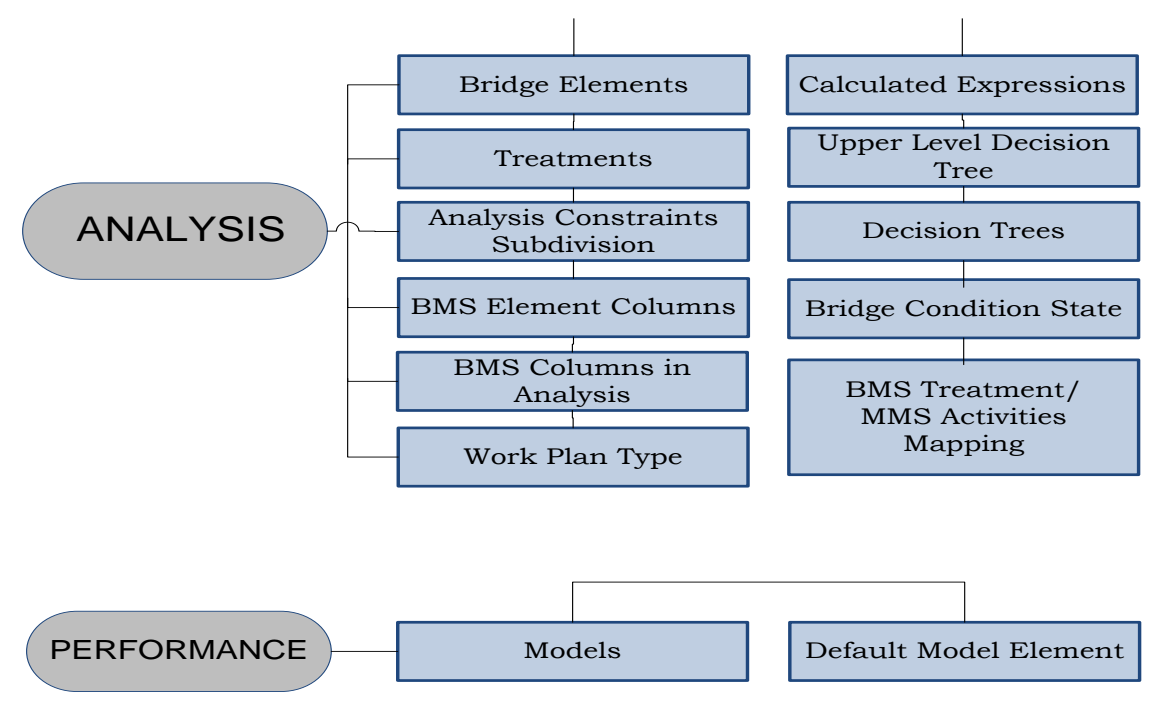

Gambar 7. Modul Setup dan Database Jembatan


Gambar 8. Modul Analisis Jembatan.

d. Modul Manajemen Keselamatan

Sistem analisis-pelaporan Keselamatan dapat dilihat pada Gambar 9.

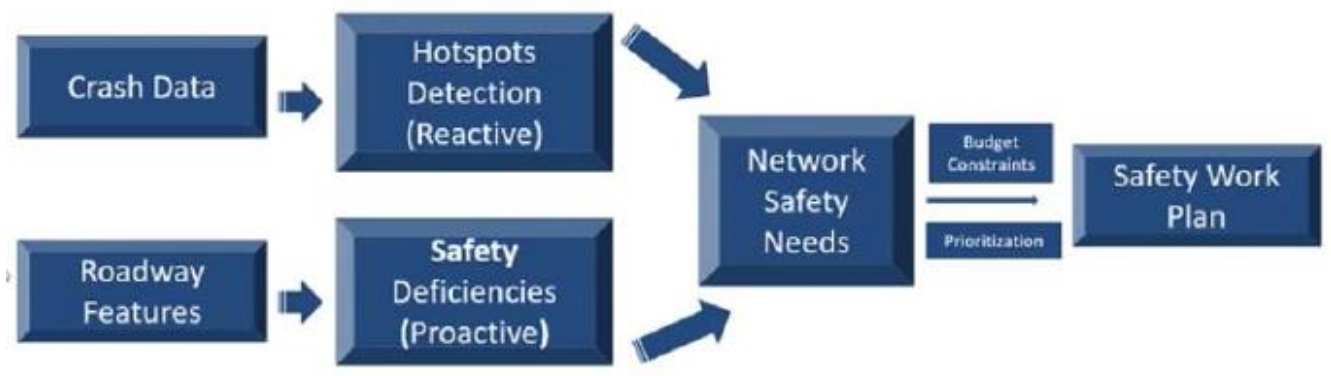

Gambar 9. Analisis Keselamatan

Secara garis besar menu dan fungsi yang terdapat pada Modul Keselamatan terdiri dari bagian Setup dan Database, Analisis, dan Reports. Pada bagian Setup dan Database terdapat Menu seperti Gambar 10. 


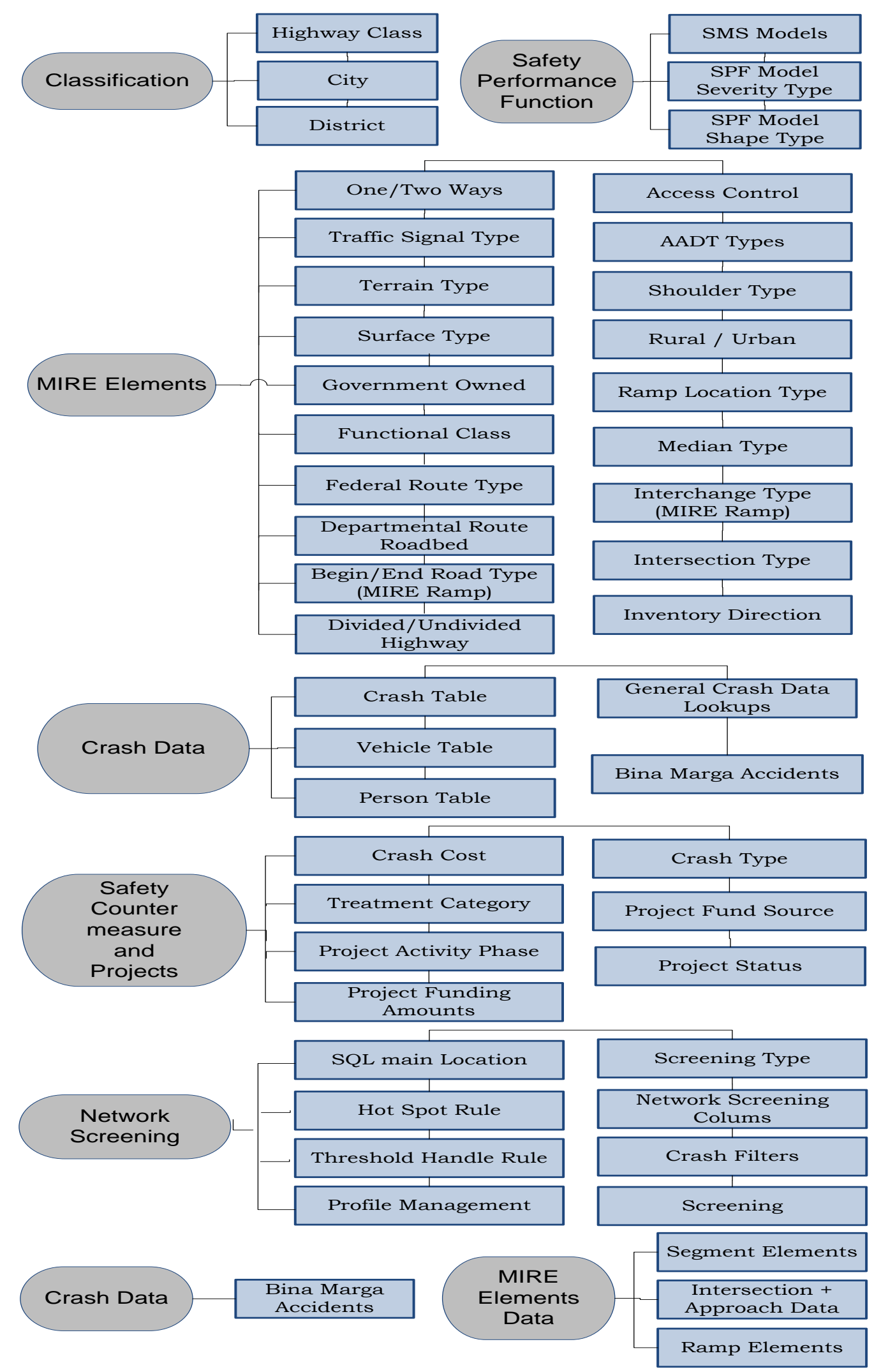

Gambar 10. Modul Setup dan Database Keselamatan 
Pada bagian Analisis terdapat Menu seperti Gambar 11. Sedangkan Pelaporan dapat ditampilkan dalam bentuk Peta GIS, Laporan (Reports) dan Dashboards.

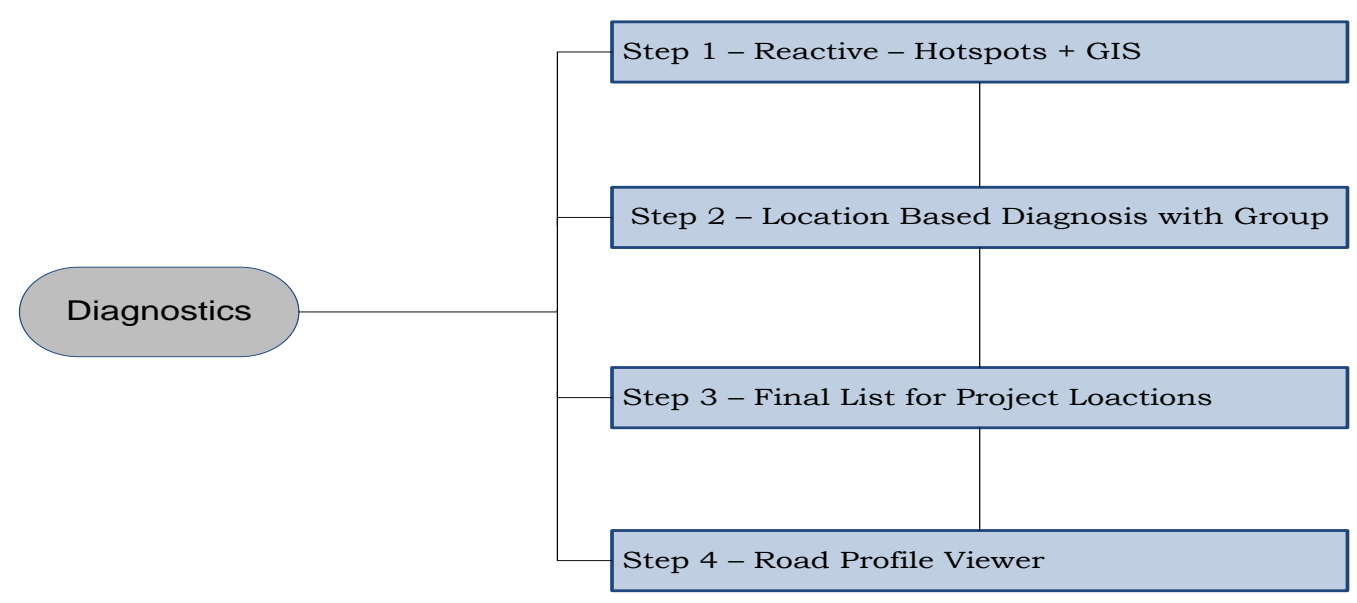

\section{Counter}

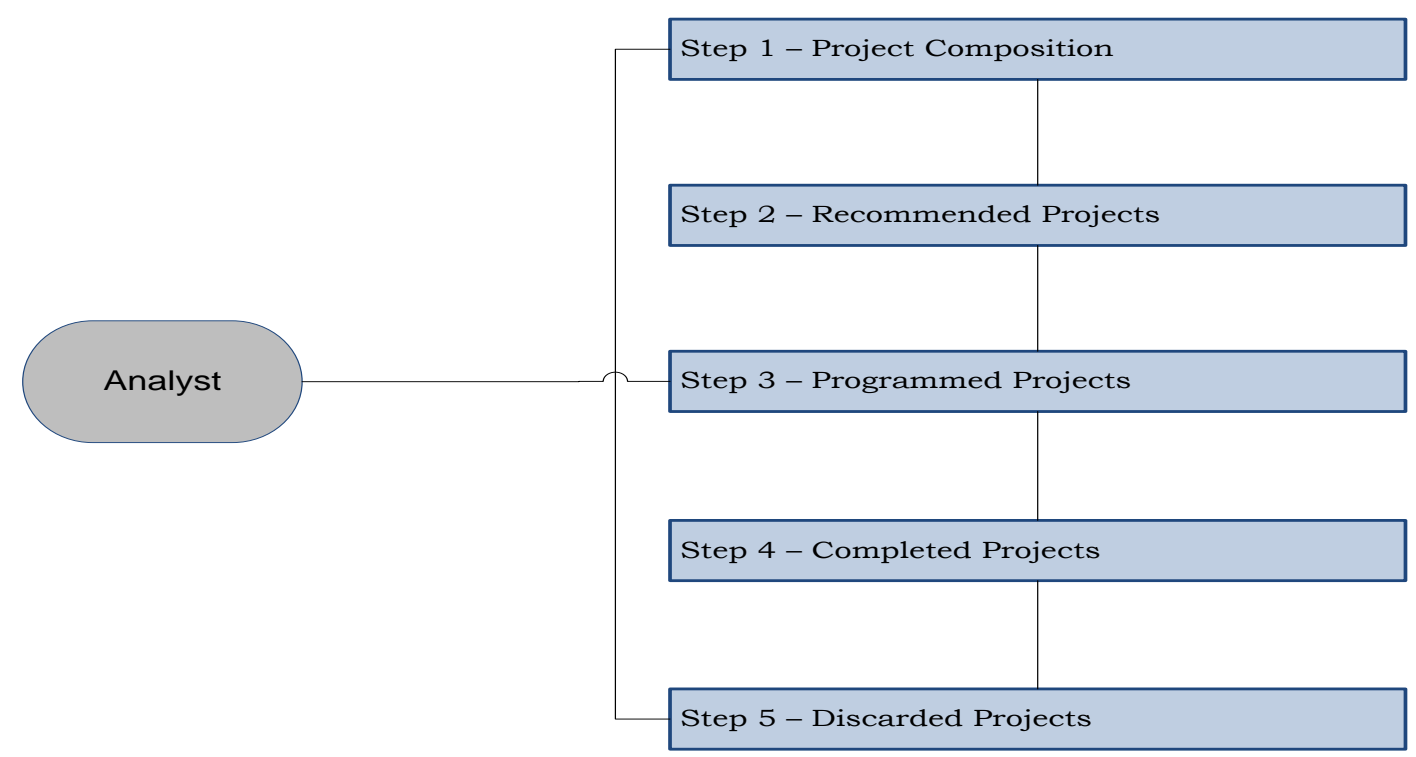

Gambar 11. Modul Analisis Keselamatan. 


\section{KESIMPULAN}

Adanya penerapan aplikasi IRMS dapat membantu pimpinan di Direktorat Jenderal Bina Marga dalam penyusunan program perencanaan, anggaran, serta pembangunan, pemeliharaan jalan, dan jembatan serta didukung dengan data keselamatan pengguna yang dapat membantu dalam perancangan jalan dan jembatan. Ketersediaan data yang lengkap dan akurat adalah menjadi suatu hal yang yang penting dalam aplikasi IRMS. Oleh karena itu, Aplikasi IRMS ini memerlukan adanya keakuratan data sehingga kegiatan survei yang efisien dan efektif sangat diperlukan.

Untuk mengoptimalisasi pelaksanaan survei di lapangan maka diperlukan alat bantu alat GPS Tracking, dan kamera digital. Selain itu, perlu didukung dengan kegiatan penginput-an data agar aplikasi Indonesia Integrated Road Management System (IRMS) dapat dimanfaatkan secara optimal.

\section{DAFTAR PUSTAKA}

[1] ArcGIS. (2019). Create and Share Maps, Analytics, and Data . https://desktop.arcgis.com/en/. Diakses 12 Agustus 2020.

[2] Direktorat Jenderal Bina Marga, 2014, Pavement, Bridge Management System and Safety Training Booklet.

[3] Oracle.(2019). Oracle Database Documentation. . https://support.oracle.com/knowledge/. Diakses 11 Agustus 2020. 